\title{
Postharvest Quarantine Treatments for Diaphorina citri on Infested Curry Leaves
}

\author{
D. J. Anco, North Carolina State University, National Science Foundation Center for Integrated Pest Management, Raleigh 27606; and United \\ States Department of Agriculture-Agricultural Research Service (USDA-ARS) United States Horticultural Research Laboratory, Fort Pierce, \\ FL 34945; and G. H. Poole and T. R. Gottwald, USDA-ARS United States Horticultural Research Laboratory
}

\begin{abstract}
Anco, D. J., Poole, G. H., and Gottwald, T. R. 2015. Postharvest quarantine treatments for Diaphorina Citri on infested curry leaves. Plant Dis. 99:926-932.

Studies were conducted to evaluate treatments that reduce survival and attachment of Diaphorina citri nymphs on infested curry leaves (Bergera koenigii). Decontamination of curry leaves infested with $D$. citri in relation to disinfectant (none or Pro-San), temperature $\left(0,40\right.$, and $\left.50^{\circ} \mathrm{C}\right)$, and treatment duration $(0,5,10$, and $20 \mathrm{~min})$ was examined using a split-split plot design. Experiments were performed three times. Treatment duration did not significantly affect $D$. citri nymph survival or removal $(P>0.2)$. Temperature and disinfectant each significantly affected $D$. citri nymph survival and removal $(P<0.031)$. The interaction of temperature and disinfectant was significant with respect to nymph survival $(P<0.0001)$ but

did not significantly affect removal $(P=0.4589)$. Tissue damage was significantly affected by temperature $(P=0.0056)$, duration $(P=0.0023)$, the interaction of temperature and duration $(P=0.0320)$, and the interaction of disinfectant, temperature, and duration $(P=0.0410)$. Of the treatments resulting in $100 \%$ D. citri nymph mortality on infested curry leaves, $40^{\circ} \mathrm{C}$ for $5 \mathrm{~min}$ with Pro-San was accompanied with the least proportion of curry leaf tissue damage $(0.14$ greater than untreated control, $P=0.25)$. Results from these studies may be useful in formulation of future regulatory policies regarding trade of citrus foliage, especially those used as condiments.
\end{abstract}

Huanglongbing (HLB) has been considered the most devastating disease of citrus (Bové 2006; Gottwald 2010; McClean and Schwarz 1970). Although promising progress is being made, there is currently no cure for this disease. The bacterium and vector associated with HLB in Florida are 'Candidatus Liberibacter asiaticus' and Diaphorina citri Kuwayama (Hemiptera: Psyllidae) (Asian citrus psyllid), respectively. Foliage of citrus and its relatives serves a variety of purposes, from decorations (e.g., Citrus limon leaf garlands and wreaths) to medicinal uses (Ferguson and Spann 2010). For example, Bergera koenigii (L.) Spreng. (syn. Murraya koenigii) has many important uses within traditional Ayurvedic medicine, including relief from vomiting, diarrhea, inflammation, and numerous other conditions (Jain et al. 2012). Additionally, leaves of B. koenigii have been widely used for centuries in Indian cooking (Jain et al. 2012), and C. hystrix leaves are commonly used in Thai cooking (Bastyra and Johnson 2007).

Citrus relatives' leaves are increasingly traded internationally, and accompanying this is the concern of pest (e.g., D. citri) and pathogen (e.g., 'Ca. L. asiaticus') movement. At present, precautionary decontamination treatment options prior to international importation of $B$. koenigii or $C$. hystrix foliage into the United States consist of treatment with methyl bromide for $2 \mathrm{~h}$ at $48 \mathrm{~g} \cdot \mathrm{m}^{-3}\left(3 \mathrm{lb}\right.$. per $\left.1,000 \mathrm{ft}^{3}\right)$ at $10^{\circ} \mathrm{C}$ or irradiation at $400 \mathrm{~Gy}$ (USDA 2013). Although both of these current methods have many beneficial qualities for quarantine and preshipment applications (e.g., effective biocide, noncorrosive, and efficient area treatments; US EPA 1986, 2009), they simultaneously have numerous drawbacks. Irradiation requires a dedicated facility that is expensive to build, although operating costs can become economical compared with other treatment options (e.g., steam treatment) when a minimum capacity of samples are treated (Venugopal 2005). Methyl bromide causes stratospheric ozone depletion and is highly toxic and hazardous to work with (Butler and Rodriguez 1996; UNEP

Corresponding author: D. J. Anco; E-mail: dan.anco@ars.usda.gov

Mention of trade names or commercial products used does not imply endorsement or recommendation by the USDA.

Accepted for publication 1 February 2015.

http://dx.doi.org/10.1094/PDIS-12-14-1271-RE

This article is in the public domain and not copyrightable. It may be freely reprinted with customary crediting of the source. The American Phytopathological Society, 2015.
2007; US EPA 2010). Although use of methyl bromide for quarantine (and preshipment) purposes is covered by an exemption from the Montreal Protocol, several countries have passed legislation to discontinue its use (Russian Federation) or have indicated that they will soon end such use (European Community and Brazil) (US EPA 2010). Furthermore, alternatives to methyl bromide for quarantine treatment have been sought, and it is the policy of the International Plant Protection Convention that, where possible, methyl bromide alternatives should be used (US EPA 2010). Previous studies have reported immersion in hot water to be applicable for quarantinelevel disinfestation (Durgapal et al. 1969; Follett and Sanxter 2001; Gaur et al. 1984; Rao and Durgapal 1967; Shellie and Mangan 2002). The objective of the current studies was to examine effects of postharvest water-temperature treatments alone and in combination with a disinfectant on survival and removal of $D$. citri nymphs on infested curry (B. koenigii) leaves.

\section{Materials and Methods}

Effect of postharvest treatments on $D$. citri survival on and removal from infested curry leaves. Curry trees were grown in a greenhouse in single-plant cups $(16 \mathrm{~cm}$ in diameter by $16 \mathrm{~cm}$ in height). Three trees each were placed within six insect-rearing tents (mesh aperture $=0.16 \mathrm{~mm}$; BugDorm-2120F; MegaView Science Co., Ltd., Taichung, Taiwan). Four weeks prior to each infestation, plants were pruned to induce a new flush of leaves. Plants were infested by placing cuttings of curry leaves with $D$. citri adults (approximately 120 adults per tent) within each tent. Adult $D$. citri were propagated from approximately 20 individuals from a (' $\mathrm{Ca}$. L. asiaticus'negative) colony maintained at the U.S. Horticultural Research Laboratory, Fort Pierce, FL. Approximately 3 weeks after initiation of infestation, leaves with $D$. citri nymphs (minimum number of nymphs per leaf $=4$ and average number of nymphs per leaf $=$ approximately 14 ) were arbitrarily detached, placed within resealable plastic bags, and stored at $10^{\circ} \mathrm{C}$ overnight. The next day, treatments were applied by submerging leaves held between T-304 stainless-steel bolting cloth (mesh aperture $=$ approximately 0.32 by $0.32 \mathrm{~mm}$ and wire diameter = approximately $0.10 \mathrm{~mm}$ ) in a temperature-controlled recirculating water bath similar to that used by Anco et al. (2014). A nymph-proof gasket at mating interfaces of screen perimeters was formed using polyvinylchloride foam tape $(0.635 \mathrm{~cm}$ thick by $1.27 \mathrm{~cm}$ wide; Foamtapes.net, West Deptford, NY). The water bath was constructed around a 160-liter cooler (Tropical Ice Boxes cooler; Braid Products, Palmdale, CA). Water was heated and cooled via an 11-kW CAST-X 3000 water heater 
(Cast Aluminum Solutions, Batavia, IL) and an Arctica DA-1000B chiller (JBJ Lighting, Inglewood, CA), respectively. A Flojet 4100-500-115 pump (Xylem Flojet, Irvine, CA) provided turbulence and circulation within the water bath. Bath temperature was monitored in 2-s intervals using DASYLab V11 (Measurement Computing, Norton, MA) as the average of four T-type 20-gauge thermocouples (Omega, Stamford, CT). One thermocouple was positioned in each of the four corners of the water bath at half the height of the water level. Actual temperatures (standard error) maintained in the temperature-controlled recirculating water bath corresponding to target treatment temperatures of 0,40 , and $50^{\circ} \mathrm{C}$ were $0.5(0.007), 40.2(0.009)$, and $49.9^{\circ} \mathrm{C}(0.009)$, respectively. Screens were arbitrarily removed from the water bath after 5, 10, and 20 min of treatment, after which leaves were examined for live and dead $D$. citri nymphs, as well as those that were removed from leaves and trapped by screens that were alive or dead. For treatments with Pro-San (Pro-San LC; active ingredients: lactic acid, phosphoric acid, citric acid, sodium acid pyrophosphate, sodium dodecylbenzene sulfonate, and sodium benzoate; Microcide, Inc., Detroit), the effective $\mathrm{pH}$ range (2.2 to 2.8 ) was reached by adding approximately $710 \mathrm{ml}$ of Pro-San to the water bath (working water volume $=140$ liters). The average $\mathrm{pH}$ of the untreated tap water was 5.5. Water bath $\mathrm{pH}$ was determined via colorpHast $\mathrm{pH}$ test strips (EMD Chemicals Inc., Darmstadt, Germany). Sample size for each treatment was 12 leaves, because preliminary experimentation indicated that sample sizes $\geq 12$ leaves (up to 20) resulted in similarly minimized estimated mean variances of numbers of nymphs per leaf compared with smaller sample sizes. Experimental design was a split-split plot, with disinfectant assigned to whole-plots, temperature assigned to subplots, and treatment duration assigned to subsubplots. The experiment was performed three times.

Effect of postharvest treatments on leaf appearance. Fourteen days posttreatment (storage at $10^{\circ} \mathrm{C}$ ), proportion of tissue damage was estimated from five representative curry leaves per treatment (or untreated control). Digital images were taken with a Canon EOS 10D digital camera (Canon USA, Inc., Melville, New York) at a standardized distance of $32 \mathrm{~cm}$. Pixels were classified as healthy or damaged using Photoshop CS4 (Adobe Systems, Inc., San Jose, CA), from which proportion of tissue damage was calculated. Pixels were converted to square millimeters via multiplying by $29^{2} / 440^{2}$ (determined empirically). This experiment was performed three times.

Data analysis. The GLIMMIX procedure of SAS (ver. 9.3; SAS, Cary, NC) was used to examine fits of generalized linear mixed models to the $D$. citri nymph mortality and removal data. The best fitting models were linear models fit to mean proportion of $D$. citri nymph death and removal. Fixed-effect factors in the final models were temperature, disinfectant, and their interaction term. All fixed effects involving duration were not significant $(P>0.2)$; thus, duration was removed from the models. Random effects corresponding to whole-plot (replication-disinfectant), subplot (replication-disinfectant-temperature), and sub-subplot error

Table 1. Terms regarding the negative exponential relationship between proportion of tissue damage of curry leaves 14 days posttreatment and terminal leaf area

\begin{tabular}{llcr}
\hline Term $^{\mathbf{a}}$ & \multicolumn{1}{c}{ Value $(\mathbf{S E})^{\mathbf{b}}$} & $\boldsymbol{t}$ Value & \multicolumn{1}{c}{$\boldsymbol{P}$} \\
\hline Robust pseudo- $\boldsymbol{R}^{2}$ & $0.3936(\ldots)$ & $\ldots$ & $\ldots$ \\
$\quad$ Concordance correlation & $0.8798(\ldots)$ & $\ldots$ & $\ldots$ \\
$\quad$ coefficient & & & \\
$\alpha$ & $0.3085(0.06388)$ & 4.83 & $<0.0001$ \\
$\beta$ & $0.5202(0.1540)$ & 3.38 & 0.0026 \\
$\boldsymbol{s}_{\varepsilon}^{2}$ & $0.02321(0.001974)$ & 11.75 & $<0.0001$ \\
$\boldsymbol{s}_{T}{ }^{2}$ & $0.08708(0.02564)$ & 3.40 & 0.0025 \\
\hline
\end{tabular}

a Terms are fit statistics (robust pseudo- $R^{2}$ and the concordance correlation coefficient; both have an upper limit of 1 , which would represent perfect agreement), parameters ( $\alpha$ and $\beta)$, and variances of covariates $\left(s_{\varepsilon}{ }^{2}\right.$ and $\left.s_{T}^{2}\right)$.

b Standard errors (SE) are not applicable for the fit statistics. terms were estimated to be zero and were excluded from the model (Littell et al. 2007). Laplace approximation (Pinheiro and Chao 2006; SAS Institute Inc. 2011; Stroup 2013) was utilized to improve standard error estimation. One-sided contrasts of least squares means were used to determine which treatment combinations resulted in significantly less $D$. citri nymph survival or more removal compared with untreated controls. The Monte Carlo simulation method (Edwards and Berry 1987) was used to adjust contrast $P$ values for multiple comparisons.

Fixed effects from the model best fitting the tissue damage data included disinfectant, temperature, duration, and all corresponding interactions. Random effects (in addition to the residual) consisted of a subplot error term (replication-disinfectant-temperature) and an error term corresponding to the leaf area of the three terminalmost nodes per leaf (terminal leaf area [TLA]). This error term (TLA class-temperature) was incorporated into the model after observation and subsequent determination of a significant $(P<$ 0.0001 ) negative exponential relationship of the form

$$
y_{u z}=\alpha \mathrm{e}^{-\beta \mathrm{TLA}_{u}}+\mathrm{T}_{z}+\varepsilon_{u z}
$$

incorporating temperature $\left(\mathrm{T}_{z}\right)$ as a random effect, with mean 0 and variance $s_{T}^{2}$ between TLA of leaf $u$ (an inverse relative proxy for leaf age) and proportion of tissue damage (y) 14 days posttreatment of leaf $u$ treated at temperature $z$. Parameter $\varepsilon_{u z}$ represents experimental error associated with leaf $u$ treated at temperature $z$ (mean 0 and variance $s_{\varepsilon}{ }^{2}$ ), while both $\alpha$ and $\beta$ are parameters representing abstract predicted proportion of tissue damage at TLA 0 and the rate of decrease in predicted proportion of tissue damage as TLA increases, respectively. Modeling of TLA data was performed in the NLMIXED procedure of SAS. Fit statistics (Madden et al. 2007), parameter, and covariate estimates are shown in Table 1. According to the fitted model, predicted proportion of tissue damage corresponding to TLA $\geq 325.80 \mathrm{~mm}^{2}$ was no longer significantly greater than 0.01 $(P \geq 0.06)$. This yielded an empirically derived threshold beyond which TLA class was subsequently undifferentiated. Classes of TLA were as follows: $1<45.01 \leq 2<77.32 \leq 3<116.25 \leq 4<$ $165.28 \leq 5<231.78 \leq 6<325.80 \mathrm{~mm}^{2} \leq 7$. As a note, none of the sampled leaves possessed TLA equal to class boundaries. TLA class boundaries were calculated as the midpoint of adjacent TLA class midpoints, which were determined by inputting midpoints of intervals (six classes, each approximately 0.038 wide) of proportion of tissue damage from the range of observed values (approximately 0.057 to 0.28 ) preceding the previously mentioned threshold of $325.80 \mathrm{~mm}^{2}$ into the fitted negative exponential model. Categorizing TLA into seven classes produced the best fitting model among the range examined (two through eight classes). Because inclusion of the whole-plot error term (replication-disinfectant) and the effect of replication did not improve fit of the model to the data, these terms were excluded from the final model. Laplace approximation was used. One-sided contrasts of least squares means were used to determine which treatment combinations resulted in significantly more curry leaf tissue damage compared with untreated controls. Here, contrast $P$ values were not adjusted for multiple comparisons to more stringently scrutinize amounts of posttreatment tissue damage.

\section{Results}

Effect of postharvest treatments on $D$. citri survival on and removal from infested curry leaves. Proportion of $D$. citri nymph mortality without Pro-San increased with increasing temperature, and treatments with Pro-San yielded $100 \%\left(40\right.$ or $50^{\circ} \mathrm{C}$ ) or $99.49 \%$ $\left(0^{\circ} \mathrm{C}\right)$ nymph mortality. All fixed effects in the model describing proportion of nymph mortality were significant (Table 2). Mortality ranged from $35 \%\left(0^{\circ} \mathrm{C}\right.$ without Pro-San) to $100 \%$ (treatments including Pro-San or $50^{\circ} \mathrm{C}$ ) (Fig. 1A). All temperature and disinfectant treatment combinations resulted in significantly (or, in the case of $0^{\circ} \mathrm{C}$ with no disinfectant, nearly significantly) greater $D$. citri nymph mortality compared with the untreated control (Table 3). Average proportion of nymph mortality on untreated controls was 0.24 .

Across all temperatures, a significantly greater proportion of nymphs (fold difference of approximately 1.6, proportion difference 
of approximately 0.07) were removed from infested curry leaves when treatments included Pro-San $(P=0.0013$; Fig. 1B). Within the model describing proportion of nymph removal, simple effects (but not the interaction) of disinfectant and temperature were significant (Table 2). All temperature and disinfectant combinations resulted in a significantly greater proportion of nymph removal compared with the untreated control $(P<0.021)$, with the exception of treatment at $0^{\circ} \mathrm{C}$ without Pro-San $(P=0.219)$. The most removal of nymphs from curry leaves occurred following treatment at $40^{\circ} \mathrm{C}$ with Pro-San (approximately 24\%). Average proportion of nymph removal on untreated controls was 0.022 .

Effect of postharvest treatments on leaf appearance. Symptoms of tissue damage (proportions of which are shown in Fig. 2) on curry leaves 14 days posttreatment ranged from isolated watersoaked cells (more common after treatment with Pro-San) to total necrosis (more common after treatment for $20 \mathrm{~min}$ at $50^{\circ} \mathrm{C}$ ) (Fig. 3). For treatments containing Pro-San, the proportion of leaf area with watersoaked cells was exacerbated by increased treatment temperature and duration (e.g., treatment at $40^{\circ} \mathrm{C}$ for $5 \mathrm{~min}$ resulted in a proportion of tissue damage of 0.17 , whereas $20 \mathrm{~min}$ at $40^{\circ} \mathrm{C}$ resulted in a proportion of tissue damage of 0.35). Significance of fixed effects and covariance parameter estimates are shown in Table 4. Average proportion of tissue damage on untreated control curry leaves after

Table 2. Type III tests of fixed effects for models describing Diaphorina citri nymph data

\begin{tabular}{llrr}
\hline Response & \multicolumn{1}{c}{ Effect } & $\boldsymbol{F}$ value & $\boldsymbol{P}$ value \\
\hline $\begin{array}{l}\text { Proportion of nymph } \\
\text { mortality }\end{array}$ & Disinfectant & 123.62 & $<0.0001$ \\
& & & \\
& Temperature & 113.15 & $<0.0001$ \\
& Disinfectant $\times$ temperature & 48.70 & $<0.0001$ \\
Proportion of nymph & Disinfectant & 4.97 & 0.0303 \\
removal & & \\
& Temperature & 8.71 & $<0.0001$ \\
& Disinfectant $\times$ temperature & 0.88 & 0.4589 \\
\hline
\end{tabular}
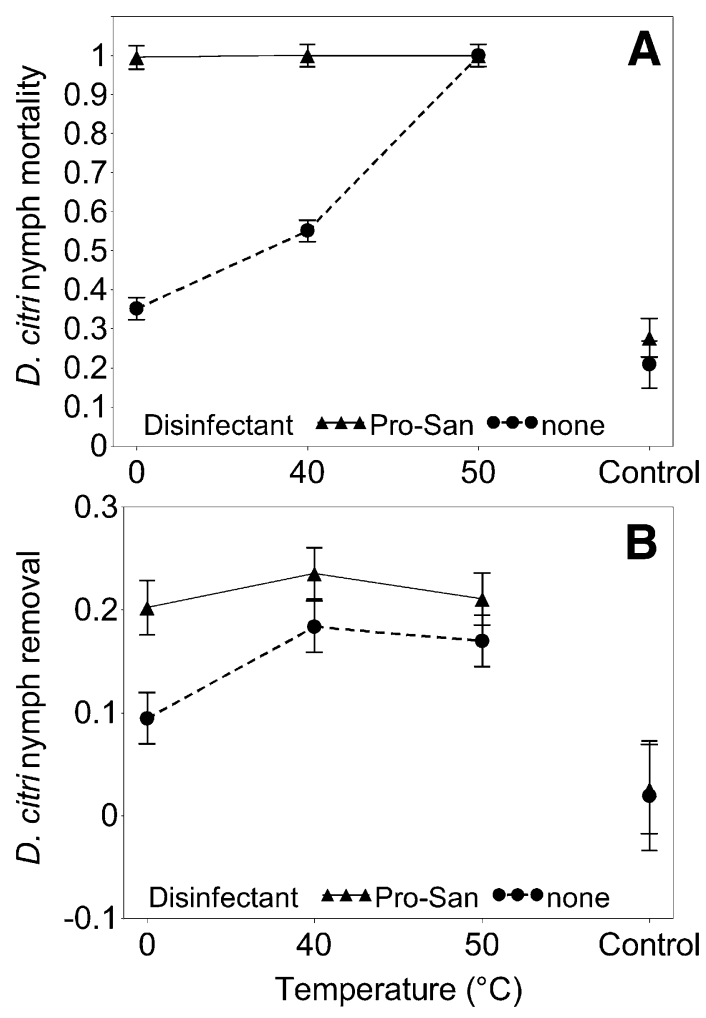

Fig. 1. Effect of temperature and disinfectant on proportion of $\mathbf{A}$, mortality and B, removal of Diaphorina citri nymphs from infested curry leaves. Error bars are standard errors of the mean of three replications.
14 days storage at $10^{\circ} \mathrm{C}$ was 0.034 . Treatments resulting in significantly more tissue damage than untreated controls are shown in Table 5. Although specific examples shown (Fig. 3E) were treated at $0^{\circ} \mathrm{C}$ with Pro-San, increased tissue damage in relation to small TLA was not unique to specific treatments and was also observed on untreated controls after 14 days of storage at $10^{\circ} \mathrm{C}$.

\section{Discussion}

The current studies have contributed knowledge of efficacy of alternative postharvest treatments combining water-mediated temperature transfer, treatment duration, and an acidic disinfectant for curry leaves infested with $D$. citri nymphs. In the absence of disinfectant, D. citri nymph mortality increased with increasing temperature to $100 \%$ mortality at $50^{\circ} \mathrm{C}$. With the disinfectant, mortality was $100 \%$ after treatment at $\geq 40^{\circ} \mathrm{C}$, and nearly $100 \%$ after treatment at $0^{\circ} \mathrm{C}$. Overall, more removal occurred when treatments included the disinfectant, and the most removal occurred at $40^{\circ} \mathrm{C}$. Posttreatment tissue damage generally increased with increasing temperature and, for treatments with Pro-San, it further generally increased with increasing treatment duration. Although the nymph stage of $D$. citri was the focus of the current studies (due to their being much more difficult to remove from plant material than their adult counterparts), it was consistently observed that treatments resulting in $100 \%$ mortality of nymphs concurrently resulted in $100 \%$ mortality of $D$. citri adults.

Previous studies have demonstrated that high-temperature treatments provide quarantine-level disinfestation of pests. Follett and Sanxter (2001) reported $100 \%$ mortality of Cryptophlebia spp. (Lepidoptera) on lychee and longan fruit submerged in $49^{\circ} \mathrm{C}$ water for 16 or $20 \mathrm{~min}$. Shellie and Mangan (2002) found that immersion of large mango fruit with Mexican fruit fly (Anastrepha ludens Loew) (Diptera) in $46.1^{\circ} \mathrm{C}$ water for 110 min provided quarantine security. Hotair treatment combinations between 43 and $47^{\circ} \mathrm{C}$ for durations from 140 to $10 \mathrm{~min}$ have resulted in $100 \%$ mortality of Conotrachelus nenuphar (Herbst) (plum curculio) (Coleoptera) and A. ludens (Hallman 1998). After a longer treatment time of $240 \mathrm{~min}$ at $46^{\circ} \mathrm{C}, 100 \%$ mortality of Rhagoletis pomonella (Walsh) (Diptera) was observed on infested apple fruit (Blessington and Hallman 1999). Although similar temperature treatments (and duration $\leq 20 \mathrm{~min}$ ) were examined in the current study, the presence of significant posttreatment tissue damage on curry leaves for treatments (without Pro-San) yielding 100\% mortality rendered those treatments undesirable. Although not examined in the current study, it is possible that quarantine-level decontamination of infested curry leaves could have been reached after extended (>100 min) treatment duration at $40^{\circ} \mathrm{C}$ while also yielding statistically acceptable amounts of posttreatment tissue damage.

Although the current studies demonstrated that (visual) tissue damage observed on curry leaves treated for $5 \mathrm{~min}$ at $40^{\circ} \mathrm{C}$ with ProSan was quite low and not significantly different from untreated controls, formal measurements regarding quantity or quality of flavor volatiles in treated leaves was absent. This information would be useful, because curry leaves are largely traded for their use in culinary applications (Jain et al. 2012), and previous research has reported how flavor volatiles can be affected independently of visual characteristics (Buttery et al. 1989; McDonald et al. 1996). Nevertheless, subjective observations did indicate that the aroma quality and intensity of leaves exposed to treatments resulting in insignificant amounts of visual tissue damage were analogous to those of untreated controls. Conversely, treatments at the significantly damaging end of the spectrum (e.g., $50^{\circ} \mathrm{C}$ treatments) produced leaves with noticeably weaker aromas less characteristic of curry.

The overall best treatment from the current study, $5 \mathrm{~min}$ at $40^{\circ} \mathrm{C}$ with Pro-San, has advantages and disadvantages compared with the currently prescribed quarantine treatments of irradiation and methyl bromide treatment. With regard to irradiation, it would be anticipated that the infrastructure necessary to conduct this study's recommended treatment would be considerably less expensive, because (depending on capacity and size) building an irradiation facility ranges from U.S.\$3 to 5 million (International Consultative Group on Food Irradiation 1999). On that note, it would have been beneficial if the current studies included treatments at room temperature 
because, based on the mortality and tissue damage data, it is quite plausible that $100 \%$ D. citri nymph mortality would have occurred after a room-temperature treatment with Pro-San for 5 min, with potentially even less associated tissue damage. If, indeed, this was the case, resulting infrastructure requirements would be further simplified and even more economical. The current studies also made no attempt to dry treated leaves before storing them in resealable plastic bags. Under an importation for subsequent trade scenario, it would perhaps be desirable to dry treated leaves. An easy way to do this would be a conveyor belt coupled with forced air. A great advantage of irradiation and methyl bromide is their versatility in treating multiple target organisms, as well as irradiation's applicability toward industrial use (e.g., sterilization of medical or scientific equipment). In the case of irradiation, facility versatility serves to offset, to an extent, costs of construction and operation. Although it is plausible that effective treatments from the current study would be effective against other pests of quarantine concern, experimental data would need to be established before expanded use of these treatments could be confidently executed.

Continued use of methyl bromide for quarantine decontamination stems from multiple considerations. Many importation situations leave methyl bromide as the only economical and practical treatment option (US EPA 2010). Often, ports of entry do not have applicable infrastructure to accommodate alternative treatments, and removal of imported materials from packaging containers costs additional time and labor (US EPA 2010). Methyl bromide has the corresponding advantage of potentially requiring minimal equipment to conduct treatments, because fumigation can be performed with as little as a sealed tarp, though more elaborate setups would be required to allow for fume recapture (US EPA 2010), due to the hazardous nature of the chemical, as described earlier. Conversely, Pro-San is nontoxic, free of volatile organic compounds, benign to work with, and environmentally friendly (Microcide 2002). In addition, and in contrast to irradiation (McGuire 2000), treatment with quarantine levels of methyl bromide has been shown to result in significant adverse effects on treated plant tissues: reduced quality, marketability (MBTOC 2007), and shelf-life (US EPA 2010). With explicit reference to curry leaves, quarantine-level treatment with methyl bromide resulted in leaves more than 50\% decayed 6 days posttreatment (McGuire 2000), which is considerably more than the approximately $17 \%$ proportion of tissue damage observed on curry leaves 14 days posttreatment with Pro-San at $40^{\circ} \mathrm{C}$ for $5 \mathrm{~min}$ (which is also $115 \mathrm{~min}$ shorter than currently prescribed methyl bromide treatment) from the current studies. With respect to potential obstacles in creating infrastructure at ports of entry to conduct this alternative treatment, an option would be for exporting countries to conduct this as a preshipment treatment, which could further reduce treatment costs compared with postentry treatment (US EPA 2010).

One potentially perceivable weakness of the current curry studies is that the results are based on experiments using an essentially clonal population of $D$. citri nymphs. This resulted in a negligible amount of genetic diversity of the sample of insect pests tested and would certainly raise critical speculation as to the relevancy of resulting "effective treatments" if the crux of those "effective treatments" was based on variables (e.g., upper or lower lethal temperatures) in response to which phenotypic plasticity of tolerable conditions could be influenced based on the geographical (e.g., latitudinal) origin or diversity of pest populations (Addo-Bediako et al. 2000). However, the ultimate result of the current studies (determination of $5 \mathrm{~min}$ at $40^{\circ} \mathrm{C}$ with Pro-San as the best evaluated treatment producing

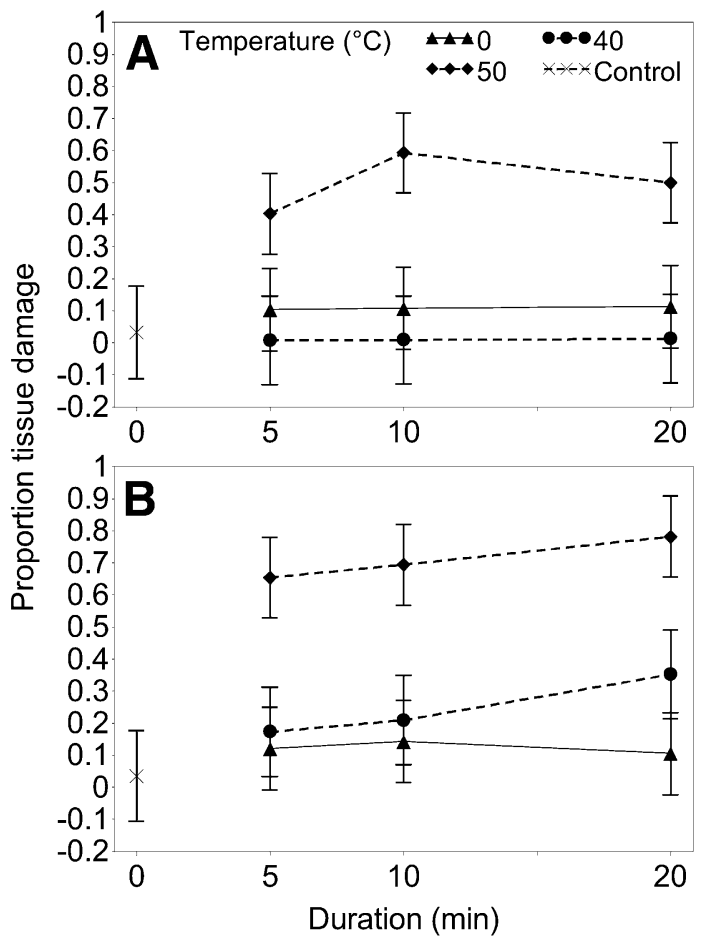

Fig. 2. Effect of treatment duration at different temperatures in the A, absence and B, presence of the disinfectant Pro-San on proportion of tissue damage on curry leaves 14 days posttreatment. Error bars are standard errors of the mean of three replications.

Table 3. Proportion of Diaphorina citri nymph mortality and removal posttreatment and contrasts with untreated controls

\begin{tabular}{|c|c|c|c|c|c|}
\hline \multirow[b]{2}{*}{ Response } & \multirow[b]{2}{*}{ Treatment } & \multirow[b]{2}{*}{ Estimate (SE) } & \multicolumn{3}{|c|}{ Contrast with untreated control $^{a}$} \\
\hline & & & Estimate (SE) & $t$ Value & $P$ value $^{\mathbf{b}}$ \\
\hline \multirow[t]{8}{*}{ Mortality } & $0^{\circ} \mathrm{C}$ & $0.3515(0.02829)$ & $0.1426(0.06634)$ & 2.15 & 0.0501 \\
\hline & $40^{\circ} \mathrm{C}$ & $0.5507(0.02829)$ & $0.3417(0.06634)$ & 5.15 & $<0.0001$ \\
\hline & $50^{\circ} \mathrm{C}$ & $1.0000(0.02829)$ & $0.7911(0.06634)$ & 11.92 & $<0.0001$ \\
\hline & $0^{\circ} \mathrm{C}$, Pro-San & $0.9949(0.03000)$ & $0.7860(0.06709)$ & 11.72 & $<0.0001$ \\
\hline & $40^{\circ} \mathrm{C}$, Pro-San & $1.0000(0.02829)$ & $0.7911(0.06634)$ & 11.92 & $<0.0001$ \\
\hline & $50^{\circ} \mathrm{C}$, Pro-San & $1.0000(0.02829)$ & $0.7911(0.06634)$ & 11.92 & $<0.0001$ \\
\hline & Control & $0.2089(0.06001)$ & $\ldots$ & $\ldots$ & $\ldots$ \\
\hline & Control, Pro-San & $0.2770(0.04900)$ & $\ldots$ & $\ldots$ & $\ldots$ \\
\hline \multirow[t]{8}{*}{ Removal } & $0^{\circ} \mathrm{C}$ & $0.09452(0.02509)$ & $0.07540(0.05885)$ & 1.28 & 0.2192 \\
\hline & $40^{\circ} \mathrm{C}$ & $0.1836(0.02509)$ & $0.1645(0.05885)$ & 2.79 & 0.0121 \\
\hline & $50^{\circ} \mathrm{C}$ & $0.1699(0.02509)$ & $0.1507(0.05885)$ & 2.56 & 0.0202 \\
\hline & $0^{\circ} \mathrm{C}$, Pro-San & $0.2019(0.02661)$ & $0.1828(0.05951)$ & 3.07 & 0.0067 \\
\hline & $40^{\circ} \mathrm{C}$, Pro-San & $0.2355(0.02509)$ & $0.2164(0.05885)$ & 3.68 & 0.0013 \\
\hline & $50^{\circ} \mathrm{C}$, Pro-San & $0.2105(0.02509)$ & $0.1914(0.05885)$ & 3.25 & 0.0041 \\
\hline & Control & $0.01913(0.05323)$ & $\ldots$ & $\ldots$ & $\ldots$ \\
\hline & Control, Pro-San & $0.02563(0.04346)$ & $\ldots$ & $\ldots$ & $\ldots$ \\
\hline
\end{tabular}

\footnotetext{
${ }^{\text {a }} \mathrm{SE}=$ standard error.

b Adjusted for multiple comparisons via Monte Carlo simulation.
} 
$100 \%$ nymph mortality while resulting in the least amount of [nonsignificant] tissue damage among treatments yielding $100 \%$ nymph mortality) was a treatment whose effectiveness resulted primarily from those examined nymphs being immersed in a relatively intolerably acidic environment ( $\mathrm{pH}$ approximately 2.5 ). Thus, the question now becomes whether or not insect (more specifically, D. citri) $\mathrm{pH}$ tolerance varies by (geographically distinct) population of individuals or, more broadly speaking, whether or not sufficient evidence exists to support the plausibility of (relatively) currently known environmental stimuli (e.g., acidic deposition) contributing toward acidophilic adaptation by $D$. citri to such (currently) relatively extreme conditions of effective treatments proposed from the current studies. These questions bring the discussion into the realm of extremophiles and, more specifically, acidophiles. At the time of this writing, literature revealing relationships regarding variation in $\mathrm{pH}$ susceptibility or tolerance of populations of individual insect species with geographical population origin was not found. Nevertheless, the effect of this relationship would be anticipated to be negligible, as D. citri is a terrestrial organism whose known geographical range of existence does not typically exhibit a range of tropospheric-air $\mathrm{pH}$, since the diatomic tendency of hydrogen within Earth's troposphere precludes the presence of gaseous hydrons for any appreciable amount of time. Because of decreased pressure and increased electromagnetic excitation energy available, gaseous ions, including hydrons, are present within the ionosphere, at altitudes of more than $60 \mathrm{~km}$ (Banks 1968; Shawhan and Gurnett 1966); however, D. citri is not found there (or at least not living for any appreciable amount of time). Regardless, the presence of free electrons within the ionosphere could cancel out a theoretically acidic $\mathrm{pH}$ of the air there (via proton donation) resulting from prevalence of gaseous hydrons. Examples of acidophile environments include acidic or hot springs, geysers, hydrothermal vents, and sulfide ore or coal deposits (Brock 1978; Kennish 1994; Prieur 2011; Rothschild and Mancinelli 2001) (all places currently unknown to harbor living D. citri). At typical atmospheric conditions, normal rain has a slightly acidic $\mathrm{pH}$ of approximately 5.6 (US EPA 2012). This is due to the formation of carbonic acid upon combination of carbon dioxide and water, which dissociates in water to form hydronium (Joesten et al. 2006). Since the industrial revolution, anthropogenic combustion of fossil fuels has increased deposition of carbon dioxide into the atmosphere (Solomon et al. 2009). Although this has its own effects, with regard to the possibility of increased tolerance of $D$. citri to lower $\mathrm{pH}$ values of rain potentially resulting from an increased tendency of the previously mentioned reactions toward formation of hydronium, the increased presence (now or future) of carbon dioxide by itself in the atmosphere is not likely to be the dominant factor in influencing this relationship. Water saturated with carbon dioxide (at approximately $35^{\circ} \mathrm{C}, 0.38 \mathrm{MPa}$ [approximately 3.75 times the pressure at sea level]) yielded a relatively measly $\mathrm{pH}$ of 3.71 (Peng et al. 2013), which has approximately 16 times less hydronium than available in treatments involving Pro-San in the current study (within the study of Peng et al. [2013], $\mathrm{pH}$ of water saturated with carbon dioxide at approximately $35^{\circ} \mathrm{C}$ reached 2.97 , but only under $15.38 \mathrm{MPa}$ [ $>151$ times the pressure at sea level]). This demonstrates the relatively slow rate of increase in acidity of water exposed to increasing concentrations of carbon dioxide, and it can quickly be predicted that atmospheric levels of carbon dioxide

Table 4. Type III tests of fixed effects and covariance parameter estimates for the model describing curry leaf tissue damage 14 days posttreatment

\begin{tabular}{|c|c|c|c|}
\hline Effect & $F$ value & $P$ value & Estimate $(\mathrm{SE})^{\mathbf{a}}$ \\
\hline Temperature & 7.31 & 0.0056 & $\ldots$ \\
\hline Duration & 6.24 & 0.0023 & $\ldots$ \\
\hline Temperature $\times$ duration & 2.69 & 0.0320 & $\ldots$ \\
\hline Disinfectant & 2.97 & 0.1040 & $\ldots$ \\
\hline Disinfectant $\times$ temperature & 0.74 & 0.4927 & $\ldots$ \\
\hline Disinfectant $\times$ duration & 2.74 & 0.0664 & $\ldots$ \\
\hline $\begin{array}{l}\text { Disinfectant } \times \text { temperature } \times \\
\text { duration }\end{array}$ & 2.53 & 0.0410 & $\ldots$ \\
\hline \multicolumn{4}{|l|}{ Covariance parameter } \\
\hline $\begin{array}{l}\text { Subplot (replication } \times \\
\text { disinfectant } \times \text { temperature) }\end{array}$ & $\ldots$ & $\cdots$ & $0.02840(0.008875)$ \\
\hline $\begin{array}{l}\text { Terminal leaf area (terminal } \\
\text { leaf area class } \times \\
\text { temperature) }\end{array}$ & $\ldots$ & $\ldots$ & $0.03127(0.01397)$ \\
\hline Residual & $\ldots$ & $\ldots$ & $0.01679(0.001504)$ \\
\hline
\end{tabular}

a $\mathrm{SE}=$ standard error.

Table 5. Treatments resulting in significantly more tissue damage than untreated controls 14 days posttreatment

\begin{tabular}{lccr}
\hline Treatment & Estimate of difference (SE) $^{\mathbf{a}}$ & $\boldsymbol{t}$ Value & $\boldsymbol{P}$ value \\
\hline $50^{\circ} \mathrm{C}, 5 \mathrm{~min}$ & $0.3705(0.1916)$ & 1.93 & 0.0272 \\
$50^{\circ} \mathrm{C}, 10 \mathrm{~min}$ & $0.5600(0.1905)$ & 2.94 & 0.0018 \\
$50^{\circ} \mathrm{C}, 20 \mathrm{~min}$ & $0.4671(0.1914)$ & 2.44 & 0.0077 \\
$50^{\circ} \mathrm{C}, 5 \mathrm{~min}$, Pro-San & $0.6184(0.1891)$ & 3.27 & 0.0006 \\
$50^{\circ} \mathrm{C}, 10 \mathrm{~min}$, Pro-San & $0.6584(0.1902)$ & 3.46 & 0.0003 \\
$50^{\circ} \mathrm{C}, 20 \mathrm{~min}$, Pro-San & $0.7461(0.1899)$ & 3.93 & $<0.0001$ \\
\hline
\end{tabular}

${ }^{\text {a }} \mathrm{SE}=$ standard error.
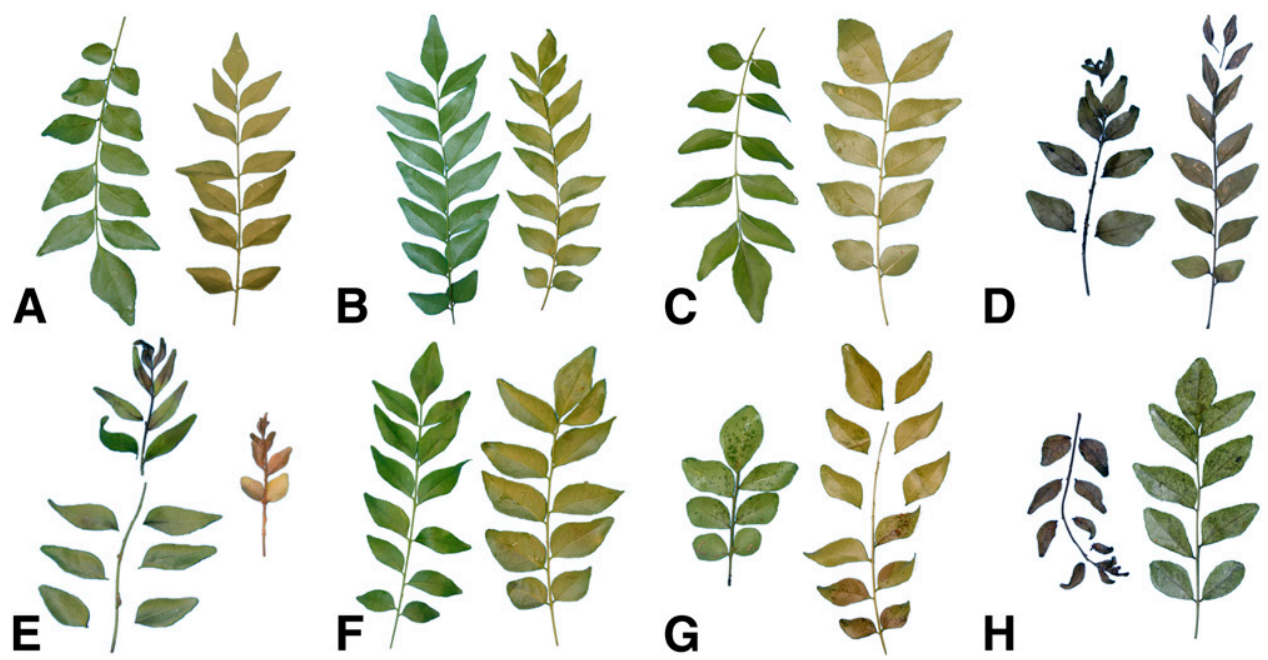

Fig. 3. Examples of tissue damage on curry leaves 14 days posttreatment. Leaves were $A$, untreated or treated at $B$ and $F, 0 ; C$ and $\mathbf{G}, 40$; or $D$ and $\mathbf{H}, 50^{\circ} \mathrm{CF}$ to $H$, with or $B$ to $D$, without the disinfectant Pro-San. E, increased tissue damage in relation to small terminal leaf area. Where applicable, leaflets were detached to facilitate imaging. 
approaching saturation would render the importance of potentially increased $D$. citri $\mathrm{pH}$ tolerance from a possible adaptation to subsequently (carbon dioxide concentration-dependent) increasingly acidic rain inconsequential.

In the absence of neutralization reactions (e.g., resulting from aerosolic mingling of alkali species [e.g., ammonium] or dust with aqueously dissociated acidic moieties [Spengler et al. 1990]), acidic deposition (e.g., acid rain) resulting from chemical reactions involving compounds other than carbon dioxide (sulfur dioxide, nitroxides, or organic acids) typically ranges in $\mathrm{pH}$ from 3.5 to 5 (Menz and Seip 2004). Globally, major citrus-producing areas (Liu et al. 2012) generally exhibit an annual $\mathrm{pH}$ of wet deposition between 4.2 and 4.5 (Rodhe et al. 2002). Even if $D$. citri were to be constantly exposed to this acidic stimulus and subsequently successfully adapt to it (not considering effects on its host or ecosystem, for that matter), it would need to do so in a matter that would allow it to tolerate approximately 66 times more extracellular hydronium in order to render the current study's effective treatments ineffective. Consideration now shifts to how acidophiles tolerate relatively acidic conditions and how closely related $D$. citri is to known acidophiles.

Mechanisms of organismal tolerance of acidic environments are essentially based on maintaining intracellular homeostasis, because adenosine triphosphate, nucleic acid, and nicotinamide adenine dinucleotide are all acid sensitive and vital to cell function (Brock 1978). More specifically, acidophiles may expel intracellular hydronium via highly active membrane-associated antiporters (proton-pumps), which may be further aided by greater than average expression of proton export enzymes, or they may prevent net proton influx via alternative permeability properties, cationic polymers on cell walls, or having robust internal pH buffering (Krulwich et al. 1998; Pick 1999; Rothschild and Mancinelli 2001). Current knowledge indicates that the most acidophilic insects can only tolerate $\mathrm{pH}$ between 2 and 3 (Rothschild and Mancinelli 2001). Exemplifying this are certain members of the Ephydridae family (e.g., Ephydra thermophila and Scatella paludum; Brock 1978). Although D. citri and Ephydrid flies are both members of the Neoptera infraclass, taxonomic divergence of the two begins at the level of superorder, with $D$. citri belonging to Paraneoptera (order Hemiptera) and Ephydrid flies to Holometabola (order Diptera) (ITIS 2014a,b). Thus, because D. citri's environment is neither continually nor nearly as acidic as treatments involving Pro-San, and D. citri is only relatively distantly related to acidophilic insects, it is unlikely (given present knowledge) that geographically distinct populations of $D$. citri would exhibit increased $\mathrm{pH}$ tolerance and, thus, be capable of surviving treatment with Pro-San, though this would have to be verified experimentally for maximal certainty. Collectively, this information supports quarantine-level effectiveness of treatment of D. citri-infested curry leaves for $5 \mathrm{~min}$ at $40^{\circ} \mathrm{C}$ with Pro-San.

\section{Acknowledgments}

Salaries and research support were provided by the Institute of Food and Agricultural Sciences, University of Florida, USDA Animal and Plant Health Inspection Service PPQ CPHST, and USDA-ARS. We thank F. Albano, G. Brock, J. Hodge, M. Ritenour, J. Smith, and L. Therrien for their contributions; D. Hall and A. Hill for their assistance in providing the initial D. citri population; and P. Nagy for posing a stimulating question.

\section{Literature Cited}

Addo-Bediako, A., Chown, S. L., and Gaston, K. J. 2000. Thermal tolerance, climatic variability and latitude. Proc. R. Soc. Lond. B 267:739-745.

Anco, D. J., Poole, G. H., and Gottwald, T. R. 2014. Effects of postharvest treatments on recovery of Xanthomonas citri subsp. citri in infected grapefruit leaves. Crop Prot. 62:115-123.

Banks, P. M. 1968. Hydrogen ion velocity distributions in the ionosphere. Planet. Space Sci. 16:759-773.

Bastyra, J., and Johnson, B. 2007. The Food and Cooking of Thailand. Hermes House, London.

Blessington, T. R., and Hallman, G. J. 1999. Hot-air quarantine treatment for apples infested with apple maggot. Subtrop. Plant Sci. 51:1-3.

Bové, J. M. 2006. Huanglongbing: A destructive, newly-emerging, century-old disease of citrus. J. Plant Pathol. 88:7-37.

Brock, T. D. 1978. Thermophilic Microorganisms and Life at High Temperatures. Springer-Verlag, New York
Butler, J. H., and Rodriguez, J. M. 1996. Methyl bromide in the atmosphere. Pages 27-90 in: The Methyl Bromide Issue. C. H. Bell, N. Price, and B. Chakrabarti, eds. Wiley, West Sussex, England.

Buttery, R. G., Teranishi, R., Flath, R. A., and Ling, L. C. 1989. Fresh tomato volatiles, composition and sensory studies. Pages 213-222 in: Flavor Chemistry, Trends and Developments. R. Teranishi, R. G. Buttery, and F. Shihidi, eds. ACS Symp. Ser. No. 388. Amer. Chem. Soc., Washington, DC.

Durgapal, J. C., Rao, Y. P., and Singh, R. 1969. Eradication of infection of Pseudomonas sesame from Sesamum seeds. Indian Phytopathol. 22:400-402.

Edwards, D., and Berry, J. J. 1987. The efficiency of simulation-based multiple comparisons. Biometrics 43:913-928.

Ferguson, J. J., and Spann, T. M. 2010. Medicinal Use of Citrus. Univ. Fla. IFAS Ext. Bull. HS892. Online publication. http://ufdc.ufl.edu/IR00003267/00001

Follett, P. A., and Sanxter, S. S. 2001. Hot water immersion to ensure quarantine security for Cryptophlebia spp. (Lepidoptera: Tortricidae) in lychee and longan exported from Hawaii. J. Econ. Entomol. 94:1292-1295.

Gaur, R. B., Ahmed, S. R., and Kataria, P. K. 1984. Controlling Xanthomonas phaseoli (Smith) Dowson of mung seed through chemotherapy and heat therapy. Hindustan Antibiot. Bull. 26:23-26.

Gottwald, T. R. 2010. Current epidemiological understanding of citrus huanglongbing. Annu. Rev. Phytopathol. 48:119-139.

Hallman, G. J. 1998. Potential quarantine treatments against plum curculio to replace methyl bromide. Pages 121-1-121-2 in: Proc. Annu. Int. Res. Conf Methyl Bromide Alternatives and Emissions Reductions, Orlando, FL.

International Consultative Group on Food Irradiation.1999. Facts about food irradiation. International Consultative Group on Food Irradiation. Online publication. http://www.iaea.org/publications/booklets/foodirradiation.pdf

ITIS. 2014a. Diaphorina citri Kuwayama, 1908. Online publication. http://www itis.gov/servlet/SingleRpt/SingleRpt?search topic=TSN\&search_value $=200477 \#$

ITIS. 2014b. Ephydra. Online publication. http://www.itis.gov/servlet/SingleRpt/ SingleRpt?search_topic $=$ TSN\&search_value $=147486$

Jain, V., Momin, M., and Laddha, K. 2012. Murraya koenigii: An updated review. Int. J. Ayurvedic Herb. Med. 2:607-627.

Joesten, M. D., Hogg, J. L., and Castellion, M. E. 2006. The World of Chemistry: Essentials. Thomson Brooks/Cole, Belmont, CA

Kennish, M. J. 1994. Practical Handbook of Marine Science. CRC Press, Boca Raton, FL.

Krulwich, T. A., Ito, M., Hicks, D. B., Gilmour, R., and Guffanti, A. A. 1998. pH homeostasis and ATP synthesis: Studies of two processes that necessitate inward proton translocation in extremely alkaliphilic Bacillus species. Extremophiles 2:217-222.

Littell, R. C., Milliken, G. A., Stroup, W. W., Wolfinger, R. D., and Schabenberger, O. 2007. SAS System for Mixed Models, 2nd ed. SAS Institute Inc., Cary, NC

Liu, Y., Heying, E., and Tanumihardjo, S. A. 2012. History, global distribution, and nutritional importance of citrus fruits. Compr. Rev. Food Sci. Food Saf. 11:530-545.

Madden, L. V., Hughes, G., and van den Bosch, F. 2007. The Study of Plant Disease Epidemics. American Phytopathological Society, St. Paul, MN.

MBTOC. 2007. 2006 Assessment Report of the Methyl Bromide Technical Options Committee. UNEP, Nairobi, Kenya.

McClean, A. P. D., and Schwarz, R. E. 1970. Greening or blotchy-mottle disease of citrus. Phytophylactica 2:177-194.

McDonald, R. E., McCollum, T. G., and Baldwin, E. A. 1996. Prestorage heat treatments influence free sterols and flavor volatiles of tomatoes stored a chilling temperature. J. Am. Soc. Hortic. Sci. 121:531-536.

McGuire, R. G. 2000. Condition of curry leaves exposed to quarantine treatments of cold, gamma irradiation, or methyl bromide fumigation. HortScience 35:888890 .

Menz, F. C., and Seip, H. M. 2004. Acid rain in Europe and the United States: An update. Environ. Sci. Policy 7:253-265.

Microcide. 2002. Pro-San LC. Microcide. Online publication. http://www microcide.com/download/1/PRO-SAN-LC

Peng, C., Crawshaw, J. P., Maitland, G. C., Martin Trusler, J. P., and Vega-Maza, D. 2013. The $\mathrm{pH}$ of $\mathrm{CO}_{2}$-saturated water at temperatures between $308 \mathrm{~K}$ and $423 \mathrm{~K}$ at pressures up to $15 \mathrm{MPa}$. J. Supercrit. Fluids 82:129-137.

Pick, U. 1999. Dunaliella acidophila a most extreme acidophilic alga. Pages 467-478 in: Enigmatic Microorganisms and Life in Extreme Environments. J. Seckbach, ed. Kluwer Academic Publishers, Dordrecht, The Netherlands.

Pinheiro, J. C., and Chao, E. C. 2006. Efficient Laplacian and adaptive Gaussian quadrature algorithms for multilevel generalized linear mixed models. J. Comput. Graph. Stat. 15:58-81.

Prieur, D. 2011. Extremophiles. Pages 572-575 in: Encyclopedia of Astrobiology, Vol. 1. M. Gargaud, R. Amils, H. J. Cleaves, M. Viso, and D. Pinti, eds. Springer Science \& Business Media, New York.

Rao, Y. P., and Durgapal, J. C. 1967. Seed transmission of bacterial blight disease of Sesamum (Sesamum orientale L.) and eradication of seed infection. Indian Phytopathol. 19:402-403.

Rodhe, H., Dentener, F., and Schulz, M. 2002. The global distribution of acidifying wet deposition. Environ. Sci. Technol. 36:4382-4388.

Rothschild, L. J., and Mancinelli, R. L. 2001. Life in extreme environments. Nature 409:1092-1101. 
SAS Institute Inc. 2011. SAS/STAT 9.3 User's Guide. SAS Institute Inc., Cary, NC. Shawhan, S. D., and Gurnett, D. A. 1966. Fractional concentration of hydrogen ions in the ionosphere from VLF proton whistler measurement. J. Geophys. Res. 71:47-59.

Shellie, K. C., and Mangan, R. L. 2002. Hot water immersion as a quarantine treatment for large mangoes: Artificial versus cage infestation. J. Am. Soc. Hortic. Sci. 127:430-434.

Solomon, S., Plattner, G.-K., Knutti, R., and Friedlingstein, P. 2009. Irreversible climate change due to carbon dioxide emissions. PNAS 106:1704-1709.

Spengler, J. D., Brauer, M., and Koutrakis, P. 1990. Acid air and health. Environ. Sci. Technol. 24:946-956.

Stroup, W. W. 2013. Generalized Linear Mixed Models: Modern Concepts, Methods and Applications. CRC Press, Boca Raton, FL.

UNEP. 2007. Methyl bromide: Quarantine and preshipment uses. United Nations Office at Nairobi, Publishing Services Section, Nairobi. Online publication. http://ozone.unep.org/Publications/UNEP-Ozone-Secretariat-MP-Brochure. pdf
USDA. 2013. United States Department of Agriculture Treatment Manual. Online publication. USDA, APHIS, PPQ. http://www.aphis.usda.gov/import_export/ plants/manuals/ports/downloads/treatment.pdf

US EPA. 1986. Pesticide fact sheet number 98: Methyl bromide. US EPA, Office of Pesticide Programs, US Government Printing Office, Washington, DC.

US EPA. 2009. Amended reregistration eligibility decision for methyl bromide (soil and non-food structural uses). EPA 738-R-09-311. US EPA, Office of Prevention, Pesticides, and Toxic Substances, Office of Pesticide Programs, Washington, DC.

US EPA. 2010. Methyl bromide alternatives for applicators, commodity owners, shippers, and their agents. Online publication. US EPA, Office of Air and Radiation Stratospheric Protection Division. http://www.epa.gov/ozone/mbr/ downloads/QPSTF_report.pdf

US EPA. 2012. Measuring acid rain. US EPA. Online publication. http://epa.gov/ acidrain/measure/index.html

Venugopal, V. 2005. Seafood Processing: Adding Value Through Quick Freezing, Retortable Packaging, Cook-Chilling, and Other Methods. CRC Press, Boca Raton, FL. 